\title{
Development of Functional Milk Beverage Powder
}

\author{
S. Niveadhitha ${ }^{1}$, D. Ramasamy ${ }^{1}$, R. Karunakaran ${ }^{2}$, A. Karthiayini ${ }^{1}$, G. Sujatha ${ }^{1}$ and \\ D. Bakaran ${ }^{1}$
}

\author{
${ }^{1}$ College of Food and Dairy Technology, Koduveli, Chennai, Tamil Nadu, India \\ ${ }^{2}$ Madras Veterinary College, Vepery, Chennai, Tamil Nadu, India
}

*Corresponding author

K e y w o r d s
$\begin{aligned} & \text { Spray drying, } \\ & \text { Beverage powder, } \\ & \text { Beetroot, Banana, } \\ & \text { Functional, Milk }\end{aligned}$
Article Info
$\begin{aligned} & \text { Accepted: } \\ & \text { 26 April } 2018 \\ & \text { Available Online: } \\ & \text { 10 May } 2018\end{aligned}$

Keywords

Spray drying, Beverage powder, Beetroot, Banana, Functional, Milk

\section{A B S T R A C T}

Beverages are no longer considered as thirst-quenchers; consumers look for specific functionality and it becomes a part of their lifestyle. In recent years, these changes and developments have led to newer products. Red beetroot (Beta vulgaris L.) is a rich source of dietary nitrate which significantly reduces systolic blood pressure in humans. Banana (Musa spp.) is a major source of potassium and total dietary fibers. Spray-drying is one of the highly utilized techniques to increase the shelf-life of food products. Hence our project was aimed to develop functional milk beverage powder with fortification of beet and banana. In our preliminary studies, various combination of milk, beetroot and banana were tried $\left(\mathrm{T}_{1}, \mathrm{~T}_{2}, \mathrm{~T}_{3}, \mathrm{~T}_{4}\right.$ and $\left.\mathrm{T}_{5}\right)$. Based on the sensory scores, $\mathrm{T}_{4}$ was selected for spray drying. Pre-heated toned milk was homogenized with pulp of banana and beetroot. The homogenized beverage was pasteurised at $85^{\circ} \mathrm{C}$ for 30 minutes and spray dried at the temperature of $140^{\circ} \mathrm{C}, 160^{\circ} \mathrm{C}$ and $180^{\circ} \mathrm{C}$ and flow rate of $100 \mathrm{ml} / \mathrm{h}, 200 \mathrm{ml} / \mathrm{h}$ and 300 $\mathrm{ml} / \mathrm{h}$. Effects of inlet air temperatures and flow rate on physical properties of spray dried functional milk beverage powder were investigated. Product yield and physical properties such as moisture content, bulk density, true density, porosity, wettability, solubility, hygroscopicity of the powder were examined. An inlet air temperature of $180^{\circ} \mathrm{C}$ caused a significant decrease in the moisture content, water activity, bulk density and solubility of the spray dried product. The increased inlet air temperature made the product more wettability.

\section{Introduction}

Beverages are considered to be an exceptional medium for the supplementation of nutraceutical components for fortification (Kuhn, 1998) such as soluble fibre or herbal extract (Swientek, 1998). The functional beverages can play a vital role in wellbeing and disease prevention. These reduce increasing encumber on health care system by an uninterrupted preventive mechanism (Shahidi, 2004). The functional beverages provide necessary nutrients to prevent nutrition-related diseases beyond taste and refreshment satisfaction (Menrad et al., 2000). There is enormous number of food products taken as beverages such as coffees, iced teas, herbal teas, sports drinks, frozen carbonated beverages, fruit and vegetable juices and smoothies (Giese, 1992). Red beetroot (Beta 
vulgaris L.) is a member of the Chenopodiaceae family grown all over the world and edible part is the root which is consumed in various forms, i.e., as fresh vegetable, juice, desiccated and frozen product and as a natural pigment. Beetroots are low in calories (about $45 \mathrm{kcal}$ per $100 \mathrm{~g}$ ) and have zero cholesterol and a minute amount of fat. This tuber contains an excellent amount of antioxidants and many other health benefiting compounds like minerals such as calcium, magnesium, iron, potassium, phosphorus, sodium and zinc, vitamins like biotin, folic acid, niacin, vitamin B6, besides soluble fiber and water soluble pigments betalains like betacyanins and betaxanthins. These have antioxidant, antiinflammatory, anti carcinogenic and hepatoprotective activities. Beetroot is a rich source of dietary nitrate and several reports indicated its potential for significantly reducing systolic blood pressure in humans. Banana is a major source of macro elements, especially potassium and contains health good ingredients such as resistant starch, total dietary fibers, rapidly digestible starch and slowly digestible starch. Its role to regulate blood pressure has been associated with the high content of potassium. Foods containing potassium can offset salt intake, as sodium and potassium work together in the body to help lower blood pressure. Milk and milk products are dietary staples of people all over the world. It is a perishable commodity and consists of valuable nutrients such as protein, fat, carbohydrate, vitamins and minerals. Processing technologies are applied to preserve milk in different forms such as condensed products, cream, butter, ice cream, powder and various forms of cheese. Spray drying is a popular technique used for milk, fruit and vegetable powders. As individual the natural fruit with additives like filler diminishes colour and vegetable powder imparts musty flavour. By mixing, the right proportion of fruit and vegetable a vibrant colour and flavourful beverage powder could be produced. In this study, functional milk beverage powder was produced using banana and beetroot. In addition to the nutritive value, banana and beetroot will act as flavouring agent and colouring agent. The addition of banana will make beetroot more palatable. Milk is used as a natural filler material which will help in sheathing the flavour and colour of the powder.

The physicochemical properties of powders produced by spray drying technique depend upon some process variables like inlet air temperature, feed flow rate, feed characteristics, etc. (Bhusari et al., 2014). Therefore, it is worthwhile to identify the ideal conditions for the production of quality functional milk beverage powder that exhibited high content of vitamin $\mathrm{C}$ and anthocyanin.

\section{Materials and Methods}

\section{Preparation of functional milk beverage}

In our preliminary studies, various combination of milk, beetroot and banana were tried $\left(T_{1}, T_{2}, T_{3}, T_{4}\right.$ and $\left.T_{5}\right)$. Based on the sensory scores, $\mathrm{T}_{4}$ was selected for spray drying. Pre-heated toned milk was homogenized with pulp of banana and beetroot. The homogenized beverage was pasteurised at $85^{\circ} \mathrm{C}$ for 30 minutes.

\section{Spray drying}

The suspension was provided to laboratory scale co-current spray dryer S.M.Scientech's (Kolkata, India) main chamber $(500 \mathrm{~mm} \mathrm{x}$ $215 \mathrm{~mm}$ ) through a peristaltic pump and a $0.5 \mathrm{~mm}$ inner diameter nozzle and the feed flow rate was controlled by the pump rotation speed. The operational conditions of the drying process were inlet air temperature and feed flow rate which were ranged between $140-180 \quad{ }^{\circ} \mathrm{C}$ and $100-300 \mathrm{ml} / \mathrm{h}$ 
respectively. The outlet temperature was kept just half to the inlet air temperature. Powder was collected in an insulated glass bottle connected at the end of cyclone after drying and packed in polyethylene pouches and stored in a desiccator containing silica gel at $25^{\circ} \mathrm{C}$ till it was further analyzed.

\section{Physicochemical properties}

\section{Yield (g)}

The yield of the spray drying process was calculated by taking into consideration the total solid content of the feed sample and weight of the final dry powder.

Yield $(\%)=\frac{W p}{F s} * 100$

Where, $\mathrm{Wp}$ is the weight of the solids of dried powder and Fs is the solid content of the feed material.

\section{Moisture content (\%)}

The moisture content was determined by AOAC 2000 method. An empty dish and the lid was dried in the oven at $105^{\circ} \mathrm{C}$ for $3 \mathrm{~h}$ and transferred to desiccator for cooling. About 3 $\mathrm{g}$ of sample to the dish was weighed and spread uniformly. The dish with sample was placed in the oven and dried for 3 hours at $105^{\circ} \mathrm{C}$. After drying, the dish with partially covered lid was transferred to the desiccator for cooling. The following equation was used to calculate moisture content on wet basis,

Moisture Content $(\%)=\frac{(W 1-W 2)}{W 1} * 100$

\section{Bulk density ( $\rho b)$}

Bulk density of the powders, which is defined as the weight of a given volume of powder, was determined according to the tapping method with some modifications.
Approximately $0.5 \mathrm{~g}$ of the powders was loosely placed into a $5 \mathrm{ml}$ measuring cylinder. The cylinder was tapped on a flat surface by hand until a constant volume was obtained. The bulk density was calculated by dividing the sample weight by the volume and expressed in $\mathrm{gcm}^{-3}$.

\section{True density ( $\rho t)$}

The ratio of mass of sample to the true volume is termed as true density of the sample. It was determined with toluene displacement method. Powder sample of about $10 \mathrm{~g}$ was submerged in toluene in measuring cylinder having an accuracy of $0.1 \mathrm{~mL}$.

The increase in liquid volume due to pouring of sample was noted as true volume of the sample, which was then used to determine the true density of sample $\left(\mathrm{gcm}^{-3}\right)$.

\section{Hygroscopicity (\%)}

Hygroscopicity was determined according to the method proposed by Cai and Corke (2000) with some modifications. Samples of each powder (approximately $1 \mathrm{~g}$ ) were placed at $25^{\circ} \mathrm{C}$ in a glass desiccator prepared with $\mathrm{NaCl}$ saturated solution $(75.29 \% \mathrm{RH})$. After one week, samples were weighed and hygroscopicity was expressed as a gram of adsorbed moisture (g/100 g) dry solids.

\section{Solubility (\%)}

The solubility was determined according to the method described by Chau et al., (2007). Briefly, samples were mixed with distilled water $(1: 10 \mathrm{w} / \mathrm{v})$, stirred for $1 \mathrm{~h}$ at room temperature and centrifuged at $1500 \mathrm{rpm}$ for $10 \mathrm{~min}$. The supernatant was collected, dried and weighed.

Solubility $(\%)=\frac{(W f)}{S} * 100$

Where, $\mathrm{W}_{\mathrm{f}}$ is the final weight $(\mathrm{g})$ of 
supernatant after drying and $S$ is the weight (g) of sample.

\section{Statistical analysis}

The experimental design and statistical analysis were performed using design expert software. A D-Optimal design was chosen, the Analysis of Variance (ANOVA) tables were generated and the effect and regression coefficients of individual linear, quadratic and interaction terms were determined. The significances of all terms in the polynomial were judged statistically by computing the Fvalue at a probability (p) of $0.001,0.01$ or 0.05. The regression coefficients were then used to make statistical calculations to generate contour maps from the regression models.

\section{Results and Discussion}

\section{Effect of inlet temperature and flow rate on yield}

The increase in inlet air temperature led to higher yield of powder, which could be attributed to the greater efficiency of heat and mass transfer processes. This was in agreement with the results published by Shrestha et al., (2007) and Shishir et al., (2016).

The increased feed flow rate had decreased yield of powder which might be caused by slow heat and mass transfer rate. Similar results were reported by Tonon et al., (2008) during spray drying of Acai pulp.

The figure 1 shows the yield of powder obtained with relation between the independent variables spray drying temperature and flow rate. The yield of powder range was in between $68.59 \%$ to $64.99 \%$. The 3D graph is the RSM graph which shows higher yield at higher spray drying temperature and lower flow rate. The best fit quadratic model was generated in RSM modelling for yield of powder was given in the equation 1 .

Yield $=+66.73+1,12 * A-0,98 * B-0,042 * A B-0,13 * A^{2}-0,20 * B^{2}$

\section{Effect of inlet temperature and flow rate on hygroscopicity}

The increase in hygroscopicity values was observed with an increase in feed flow rate. The reason for this could be defined by the lesser time for evaporation in the case of high feed flow rate. The decreasing inlet air temperature led to the decreasing hygroscopicity values which could be well explained by the increasing moisture content with lower inlet air temperature. Tonon et al., (2008) reported a similar trend of hygroscopicity values while working on spray dried acai powder. The figure 2 shows the hygroscopicity of powder obtained with relation between the independent variables spray drying temperature and flow rate. The hygroscopicity of powder obtained ranges between $16 \mathrm{~g} / 100 \mathrm{~g}$ to $22 \mathrm{~g} / 100 \mathrm{~g}$. The $3 \mathrm{D}$ graph is the RSM graph which shows higher hygroscopicity at higher spray drying temperature and higher flow rate. The best fit quadratic model was generated in RSM modelling for yield of powder were given in the equation 2 .

Hygroscopicty $=+182.1+1.30 * A+1.71 \times B+0.022 * 4 B+0.018 \times A^{2}+0.51 \times B^{2}$

\section{Effect of inlet temperature and flow rate on solubility}

According to Manickavasagan et al., (2015), Muzaffar, Dinkarrao and Kumar (2016) and Muzaffar and Kumar (2015 b) the powder produced at the lower feed rate had higher solubility which may be related to lower moisture content of the powder. 
Table.1 ANOVA table indicating the yield

\begin{tabular}{|c|c|c|c|c|}
\hline Source & $\begin{array}{l}\text { Sum of } \\
\text { squares }\end{array}$ & Df & $\begin{array}{l}\text { Mean } \\
\text { square }\end{array}$ & $\begin{array}{l}\text { p-value } \\
\text { Prob> F }\end{array}$ \\
\hline Model & 20.20 & 5 & 4.04 & $<0.0001$ \\
\hline $\begin{array}{l}\text { A-Spray } \\
\text { Drying }\end{array}$ & 8.42 & 1 & 8.42 & $<0.0001$ \\
\hline B-Flow rate & 9.82 & 1 & 9.82 & $<0.0001$ \\
\hline $\mathbf{A B}$ & 0.010 & 1 & 0.010 & 0.1422 \\
\hline $\mathrm{A}^{2}$ & 0.042 & 1 & 0.042 & 0.0088 \\
\hline$\overline{\mathbf{B}^{2}}$ & 0.078 & 1 & 0.078 & 0.0013 \\
\hline Residual & 0.040 & 4 & $4.021 \mathrm{E}-003$ & \\
\hline Lack of fit & 0.040 & 4 & 0.010 & \\
\hline Pure error & 0.000 & 6 & 0.000 & \\
\hline Cor total & 252.66 & 21 & & \\
\hline
\end{tabular}

Table.2 ANOVA table indicating the hygroscopicity

\begin{tabular}{|c|c|c|c|c|}
\hline Source & $\begin{array}{l}\text { Sum of } \\
\text { squares }\end{array}$ & Df & $\begin{array}{l}\text { Mean } \\
\text { square }\end{array}$ & $\begin{array}{l}\text { p-value } \\
\text { Prob> F }\end{array}$ \\
\hline Model & 61.90 & 5 & 12.38 & $<0.0001$ \\
\hline $\begin{array}{l}\text { A-Spray } \\
\text { Drying }\end{array}$ & 11.31 & 1 & 11.31 & $<0.0001$ \\
\hline B-Flow rate & 29.72 & 1 & 29.72 & $<0.0001$ \\
\hline $\mathbf{A B}$ & 0.57 & 1 & 0.57 & 0.0004 \\
\hline $\mathbf{A}^{2}$ & $8.140 \mathrm{E}-004$ & 1 & $8.140 \mathrm{E}-004$ & 0.8478 \\
\hline $\mathbf{B}^{2}$ & 0.53 & 1 & 0.53 & 0.0005 \\
\hline Residual & 0.21 & 10 & 0.021 & \\
\hline Lack of fit & 0.21 & 4 & 0.052 & \\
\hline Pure error & 0.000 & 6 & 0.000 & \\
\hline Cor total & 62.11 & 15 & & \\
\hline
\end{tabular}

Table.3 ANOVA table indicating the solubility

\begin{tabular}{|l|l|l|l|l|l|}
\hline Source & $\begin{array}{l}\text { Sum } \\
\text { squares }\end{array}$ & of & Df & $\begin{array}{l}\text { Mean } \\
\text { square }\end{array}$ & $\begin{array}{l}\text { p-value } \\
\text { Prob> F }\end{array}$ \\
\hline Model & 52.34 & & 2 & 26.17 & $<0.0001$ \\
\hline $\begin{array}{l}\text { A-Spray } \\
\text { Drying }\end{array}$ & 41.42 & & 1 & 41.42 & $<0.0001$ \\
\hline B-Flow rate & 16.45 & & 1 & 16.45 & 0.0026 \\
\hline Residual & 15.55 & 13 & 1.20 & \\
\hline Lack of fit & 1.34 & 7 & 0.19 & 0.9980 \\
\hline Pure error & 14.20 & 6 & 2.37 & \\
\hline Cor total & 67.89 & 15 & & \\
\hline
\end{tabular}


Fig.1 Effect of temperature and flow rate on yield

Design-Expert( Software

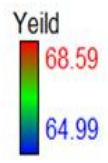

X1 = A: Spray Drying Temperature $\mathrm{X} 2=\mathrm{B}$ : Flow raate
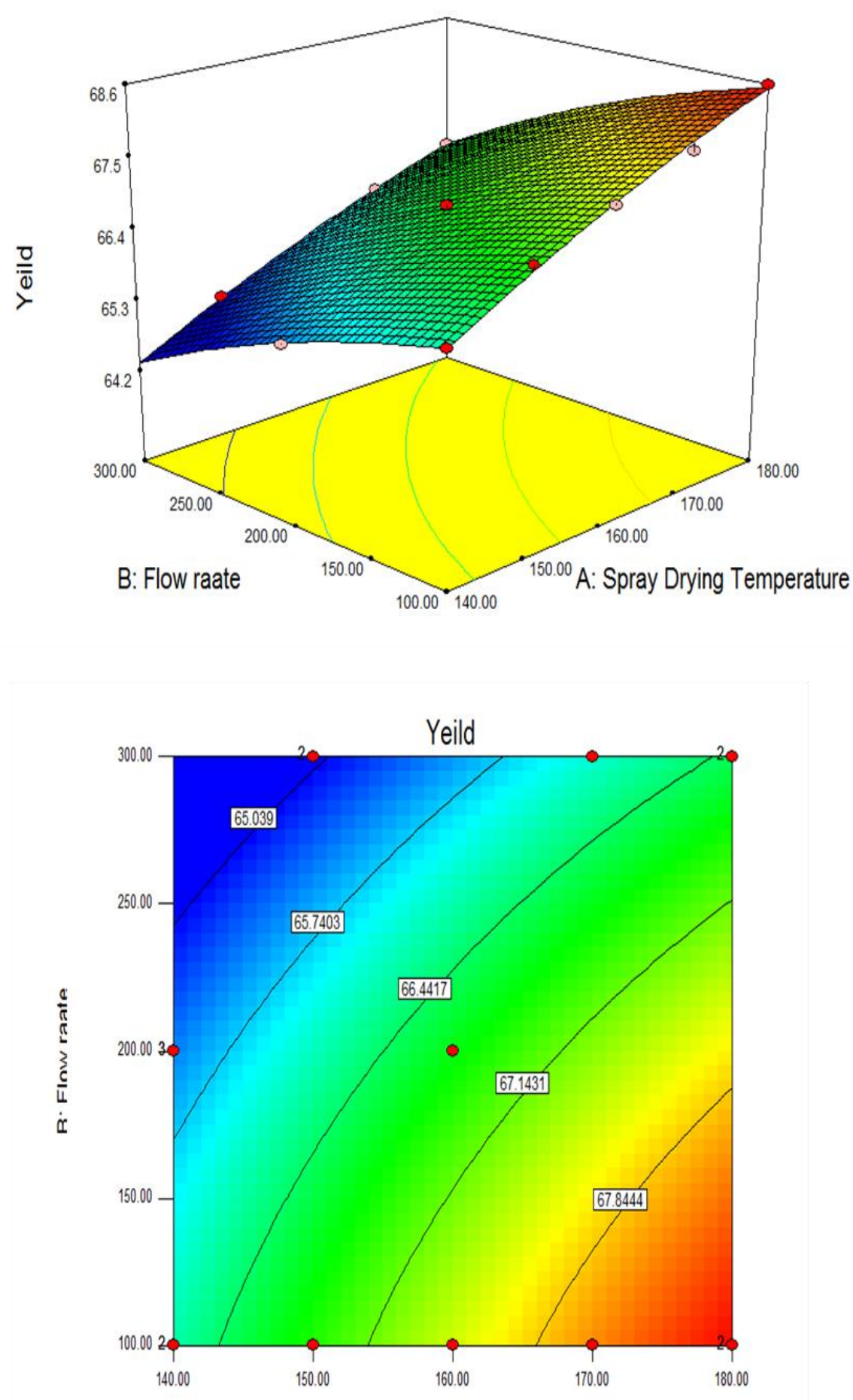

A: Spray Drying Temperature 
Fig.2 Effect of temperature and flow rate on hygroscopicity

Design-Expert(B) Software

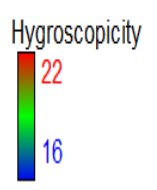

$X 1=A:$ Spray Drying Temperature $\mathrm{X} 2=\mathrm{B}$ : Flow raate
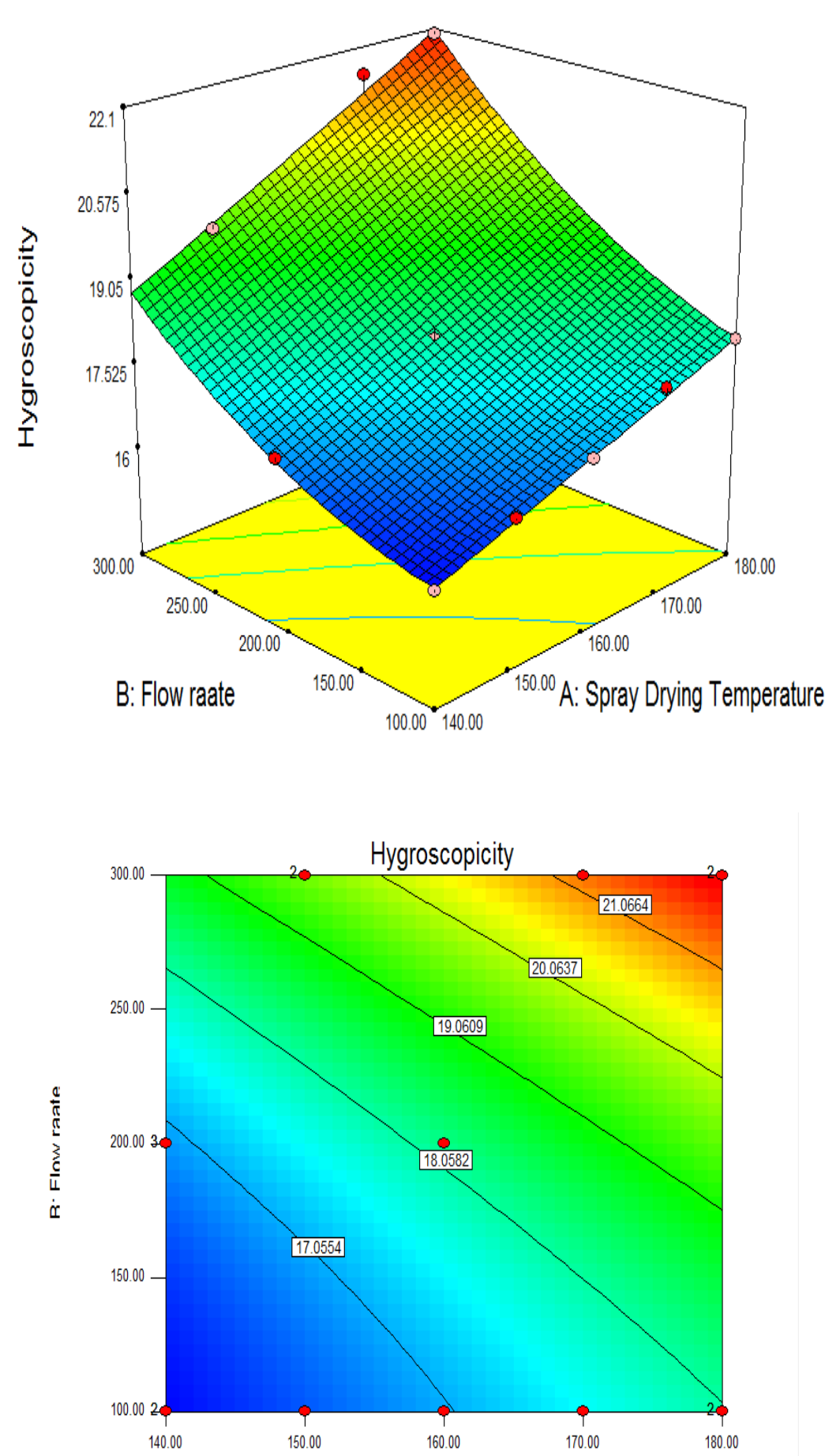

A: Spray Drying Temperature 
Fig.3 Effect of temperature and flow rate on solubility

Design-Expert@ Software

Solubility

- Design Points

65

57.25

X1 = A: Spray Drying Temperature $\mathrm{X} 2=\mathrm{B}$ : Flow raate
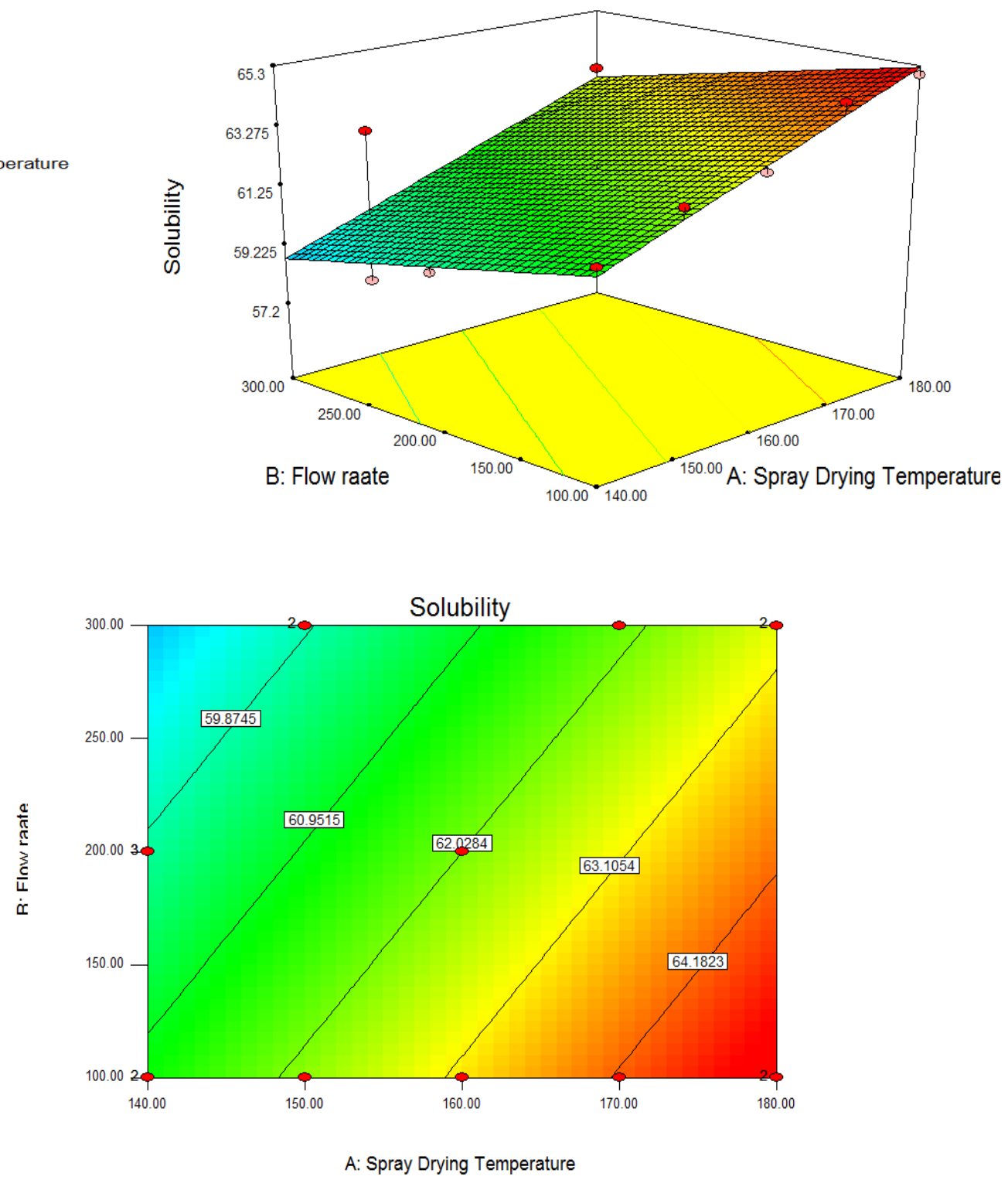

In general, the higher inlet temperature results in higher solubility. These results were reported for pitaya (Bakar et al., 2013), tomato (Goula and Adamopoulos, 2005), pomegranate (Vardin and Yasar, 2012), tamarind (Muzaffar and Kumar, 2015b), sour cherry (Moghaddam et al., 2017) and mountain tea (Nadeem et al., 2011). The increase in solubility with an increase in inlet air temperature is due to its effect on residual moisture content.

The figure 3 shows the solubility of powder obtained with relation between the independent variables spray drying temperature and flow rate. The solubility of 
powder obtained ranges between $57.25 \%$ and $65 \%$. The 3D graph is the RSM graph which shows higher solubility at higher spray drying temperature and lower flow rate. The best fit quadratic model was generated in RSM modelling for yield of powder were given in the Equation 3.

Solubility $=+62.03+2.04 * A+1.19 * B$

Significance was judged by determining the probability level that the F-static (F-Value).

The p-value of the model was $<0.0001$, which indicated the model fitness was highly significant (Table 1, 2 and 3).

The quadratic model was in good agreement with the experimental results, with $\mathrm{R}^{2}$ for yield, hygroscopicity and solubility are $0.9980,0.9966$ and 0.7710 respectively.

The numerical process optimization for spray drying of functional milk beverage powder is $180^{\circ} \mathrm{C}$ and flow rate of $100 \mathrm{ml} / \mathrm{h}$ to get the maximum yield of $68.53 \%$, hygroscopicity of $18 \mathrm{~g} / 100 \mathrm{~g}$, solubility of $65.23 \%$ and the desirability value is 0.868 .

The factor inputs used to arrive at optimization were yield, hygroscopicity and solubility. If quality parameters like colour and flavour gets included for optimization, the attained process parameters may vary.

The optimization for the process parameters for spray drying of functional milk beverage powder aiming at attaining highest yield, reduced hygroscopicity and good solubility alone points at highest temperature and lowest flow rate for drying.

An inlet air temperature of $180^{\circ} \mathrm{C}$ and flow rate of $100 \mathrm{ml} / \mathrm{h}$ caused a significant decrease in the moisture content, bulk density and true density of the spray dried product.

\section{References}

AOAC. Official methods of analysis. $17^{\text {th }}$ ed. Association of official analytical chemists, Washington DC, USA; 2000.

Bakar, J., Ee, S. C., Muhammad, K., Hashim, D. M., and Adzahan, N. (2013). Spraydrying optimization for red pitaya peel (Hylocereus polyrhizus). Food and Bioprocess Technology, 6, 1332-1342.

Bhusari, S. N., Muzaffar, K., and Kumar, P. (2014). Effect of carrier agents on physical and microstructural properties of spray dried tamarind pulp powder. Powder Technology, 266, 354-364. http://dx.doi.org/10.1016/j.powtec.2014. 06.038 .

Boukouvalas, C. J.; Krokida, M. K.; Maroulis, Z. B.; Marinos-Kouris, D. Effect of Material Moisture Content and Temperature on the True Density of Foods. Int. J. Food Prop. 2006, 9(1), 109-125. DOI: $10.1080 / 109429105$ 00473970.

Cai, Y.Z., Corke, H., 2000. Production and properties of spray-dried Amaranthus betacyanin pigments. J. Food Sci. 65, 1248-1252.

Chau, C. F. et al., Different micronization methods significantly improve the functionality of carrot insoluble fiber, Food Chem. 100, 1402-1408, 2007.

Chegini, G.R. and Ghobadian, B. 2005. Effect of spray drying conditions on physical properties of orange juice powder. Drying Technology 23: 657-668.

Giese, J.H. 1992. Hitting the spot: Beverages and beverage technology. Food Technol. 46:70-80.

Goula, A. M., and Adamopoulos, K. G. (2005). Spray drying of tomato pulp in dehumidified air: II. The effect on powder properties. Journal of Food Engineering, 66, 35-42.

Kuhn, M. E. 1998. Functional food overdose. Food Proc. Mag. 59(5):21-48. 
Manickavasagan, A., Thangavel, K., Dev, S., Aniesrani Delfiya, D., Nambi, E., Orsat, V., (2015). Physicochemical characteristics of date powder produced in a pilot scale spray dryer. Drying Technology, 33, 1114e1123.

Menrad, M., B. Husing, K. Menrad, T. Reib, S. Beer-Borst and C.A. Zenger. 2000. Functional Food. TA 37/2000. Bern: Schweizerischer Wissenschafts undTechnologierat.

Moghaddam, A. D., Pero, M., \& Askari, G. R. (2017). Optimizing spray drying conditions of sour cherry juice based on physicochemical properties, using response surface methodology (RSM). Journal of Food Science and Technology, 54, 174-184.

Muzaffar, K., \& Kumar, P. (2015). Parameter optimization for spray drying of tamarind pulp using response surface methodology. Powder Technology, 279, 179-184. http://dx.doi.org/10.1016/j. powtec.2015.04.010.

Muzaffar, K., \& Kumar, P. (2015). Parameter optimization for spray drying of tamarind pulp using response surface methodology. Powder Technology, 279, 179-184.

Muzaffar, K., Dinkarrao, B. V., and Kumar, P. (2016). Optimization of spray drying conditions for production of quality pomegranate juice powder. Cogent Food \& Agriculture, 2, 1127583.

Niro, G. E. A. (2005). Gea Niro method, No. A 5A: Wettability. Retrieved from http:// www.niro.dk/niro/cmsdoc.nsf/ WebDoc/ndkw6dknxs. On 08 August 2014.

Shahidi, F. 2004. Functional foods: Their role in health promotion and disease prevention. J. Food Sci. 69(5):146-149.

Shishir, M.R.I., Taip, F.S., Aziz, N.A., Talib, R.A., Sarker, R.S., 2016. Optimization of spray drying parameters for pink guava powder using RSM. Food Sci. Biotechnol. 25 (2), 461-468.

Shrestha, A.K., Ua-arak, T., Adhikari, B.R., Howes, T., Bhandari, B. R., 2007. Glass transition behavior of spray dried orange juice powder measured by differential scanning calorimetry (DSC) and thermal mechanical compression test (TMCT). Int. J. Food Prop. 10, 661-673.

Swientek, B. 1998. Toasts of the town. Prep. Foods. Pp: 21-26.

Tonon, V.R., Brabet, C., Hubinger, D.M., 2008. Influence of process conditions on the physicochemical properties of acai (Euterpe oleraceae) powder produced by spray drying. J. Food Eng. $88,411-418$.

Walton, D. E., Mumford, C. J. The Morphology of Spray-Dried Particles: The Effect of Process Variables upon the Morphology of Spray-Dried Particles. Chem. Eng. Res. Des. 1999, 77(5), 442-460. DOI:10.1205/ 026387699526296

\section{How to cite this article:}

Niveadhitha, S., D. Ramasamy, R. Karunakaran, A. Karthiayini, G. Sujatha and Bakaran, D. 2018. Development of Functional Milk Beverage Powder. Int.J.Curr.Microbiol.App.Sci. 7(05): 3752-3761. doi: https://doi.org/10.20546/ijcmas.2018.705.435 